\title{
Medium-dependent sporulation resulting from a mutation in the spollAB gene of Bacillus subtilis
}

\author{
David Foulger, George F. Parker and Jeffery Errington
}

Sir William Dunn School of Pathology, University of Oxford, South Parks Road, Oxford OX1 3RE, UK

\author{
Author for correspondence: Jeff Errington. Tel: +44 1865 275561. Fax: +44 1865275556. \\ e-mail: erring@molbiol.ox.ac.uk
}

\begin{abstract}
The SpollAB protein of Bacillus subtilis is an anti-sigma factor that controls the release of $\sigma^{F}$ in the prespore during sporulation. A missense mutation, spollAB22, in the $\mathbf{N}$-terminal coding portion of spollAB was isolated previously $c n$ the basis of conferring increased $\sigma^{F}$ activity on agar plates. We present the results of experiments further characterizing the phenotypic effects of the spollAB22 mutation. The mutation severely impairs spore formation on nutrient agar (NA) plates. Surprisingly, however, cultures induced to sporulate in liquid medium by the resuspension method showed little or no reduction in spore formation, and gene expression was more or less normal. The effects on sporulation on NA can be suppressed by mutations in the spollAC gene encoding $\sigma^{F}$. The implications for our understanding of the regulation of $\sigma^{F}$ and $\sigma^{\sigma}$ activities, and the nature of the apparent medium dependence of sporulation in the mutant, are discussed.
\end{abstract}

Keywords: sporulation, Bacillus subtilis, anti-sigma factor, suppressor mutations, $\sigma^{\mathrm{F}}$

\section{INTRODUCTION}

Classically, sporulation mutants of Bacillus subtilis were generally isolated as translucent unpigmented colonies on rich medium. The detailed phenotypic properties of such mutants were then usually characterized in liquid medium either by nutrient exhaustion or by resuspension (for a review see Piggot \& Coote, 1976). Mutations causing defective sporulation on some media but more or less normal sporulation on others have been described. In many cases the latter class of mutants could be assigned to a specific nutritional defect (reviewed by Freese \& Heinze, 1984). Here we describe the phenotypic properties of a mutation in a well-characterized regulatory gene, spoII $A B$, which unexpectedly causes medium-dependent sporulation.

The spoII $A B$ gene of $B$. subtilis encodes an anti-sigma factor, which inhibits the activities of $\sigma^{F}$ and probably $\sigma^{G}$ during sporulation (Duncan \& Losick, 1993; Min et al., 1993; Partridge et al., 1991; Rather et al., 1990; Schmidt et al., 1990). These sigma factors are responsible for transcription in the forespore compartment during sporulation. The action of SpoIIAB probably serves to prevent

This paper is dedicated to the memory of lain Challoner-Courtney.

Abbreviations: APase, alkaline phosphatase; MUG, 4-methylumbelliferyl$\beta$-D-galactosidase.
$\sigma^{F}$ from becoming active, both before septation, and in the mother cell compartment after septation (Margolis $e t$ al., 1991). spoII $A B$ is the middle gene of a three gene operon (Fort \& Piggot, 1984). The third gene encodes $\sigma^{F}$ itself (Errington et al., 1985; Sun et al., 1989). The first gene, spoII $A A$, encodes an antagonist of SpoIIAB, or anti-anti-sigma factor (Alper et al., 1994; Diederich et al., 1994; Schmidt et al., 1990). Presumably, SpoIIAB and possibly SpoIIAA can sense some special feature of the prespore microenvironment and regulate $\sigma^{\mathbf{F}}$ activity on the basis of this information (Lewis et al., 1994; Margolis et al., 1991). Although the biochemical basis for the interactions between these proteins is beginning to be elucidated (Alper et al., 1994; Duncan \& Losick, 1993; Min et al., 1993; Diederich et al., 1994), little is known about their regulation in vivo. An understanding of the molecular basis of the regulation of $\sigma^{\mathbf{F}}$ activity is important because $\sigma^{\mathrm{F}}$ plays a key role in triggering the complex programmes of gene expression that determine prespore and mother cell differentiation (reviewed recently: Errington, 1993; Losick \& Stragier, 1992).

Previous work on strains containing the spoII $A B 22$ mutation has shown that the mutant protein is impaired in the inhibition of $\sigma^{\mathbf{F}}$ activity, at least during growth on nutrient agar (NA) plates (Foulger \& Errington, 1993). Under these conditions spoII $A B 22$ mutants also display abnormally high levels of $\sigma^{\mathrm{G}}$ activity. However, because 
$\sigma^{\mathrm{G}}$ synthesis can be increased by transcription directed by $\sigma^{\mathbf{F}}$, it was not clear whether the mutant protein was impaired in the regulation of $\sigma^{\mathrm{G}}$ activity or whether the effect on $\sigma^{\mathrm{G}}$ was indirect. This paper describes further investigations of the phenotypic consequences of the spoII $A B 22$ mutation and the isolation and characterization of suppressor mutations that relieve its effects on sporulation.

\section{METHODS}

Bacterial strains, plasmids and bacteriophages. The strains used are listed in Table 1. Phage $\phi 105 \mathrm{~J} 114$, used to complement the spoIIGB55 mutation in strain 839 , was isolated by East \& Errington (1989). Plasmid pSG279 is a derivative of pSGMU2 (Fort \& Errington, 1985), containing a truncated derivative of the spoII $A C$ gene, stretching from an EcoRI* site 61 bp from the upstream end of the gene, to the PstI site just after the termination codon. Plasmid pPS300 (Mason et al., 1988) was a kind gift from P. Setlow (University of Connecticut Health Center, Farmington, CT, USA).

General methods. B. subtilis strains were grown on plates containing NA (Oxoid) or LB agar (Rather et al., 1990). Chloramphenicol $\left(5 \mu \mathrm{g} \mathrm{ml}^{-1}\right)$, kanamycin $\left(5 \mu \mathrm{g} \mathrm{ml}^{-1}\right)$, or erythromycin $\left(1 \mu \mathrm{g} \mathrm{ml}^{-1}\right)$ and lincomycin $\left(25 \mu \mathrm{g} \mathrm{ml}^{-1}\right)$ were added as required. $\beta$-Galactosidase activity was detected in plates by addition of $0.01 \%$ X-Gal. $B$. subtilis strains were made competent for transformation with DNA by the method of Anagnostopoulos \& Spizizen (1961) as modified by Jenkinson (1983). Transduction with bacteriophage $\phi 105$ was as described by Errington \& Mandelstam (1986). Chromosomal DNA for transformation was prepared from $B$. subtilis by the rapid method of Ward \& Zahler (1973). Chromosomal DNA for cloning experiments was prepared as described by Errington (1984). Transformation of Escherichia coli and DNA manipulations were carried out using standard procedures (e.g. Sambrook et al., 1989).

Sporulation of B. subtilis. B. subtilis cultures grown in hydrolysed casein growth media at $37^{\circ} \mathrm{C}$ were induced to sporulate by resuspension in sporulation medium (SM) (Sterlini \& Mandelstam, 1969), as specified by Partridge \& Errington (1993). Time (h) after resuspension was denoted $t_{0}, t_{1}$ etc.

Measurement of heat resistance. Heat resistance in liquid cultures was measured as described by Foulger \& Errington (1991). Samples $(0.5 \mathrm{ml})$, taken at $t_{9}$, were heated at $80^{\circ} \mathrm{C}$ for $15 \mathrm{~min}$, diluted and plates on Oxoid NA. To measure heat resistance on plates, a fresh single colony was used to heavily inoculate a NA plate. The cells from three separate plate cultures were harvested in about $5 \mathrm{ml} \mathrm{SM}$. The cell suspension was diluted in SM to an $\mathrm{OD}_{600}$ of about 2.0 (near to the value obtained with cells sporulating in liquid medium). Heat resistance was determined similarly to that of the liquid cultures by heating a $1 \mathrm{ml}$ sample of culture at $80^{\circ} \mathrm{C}$ for $15 \mathrm{~min}$.

Enzyme assays. $\beta$-Galactosidase activity was measured by assays

Table 1. Bacterial strains

\begin{tabular}{|c|c|c|}
\hline Strain & Markers & Construction/reference* \\
\hline 55.3 & $\operatorname{trpC2}$ spoIIGB55 & Errington \& Mandelstam (1986) \\
\hline 168 & $\operatorname{trp} C 2\left(\mathrm{Spo}^{+}\right)$ & Laboratory stock \\
\hline 713 & $\operatorname{trp} C 2 \Omega\left(\right.$ spoIV $A^{\prime}-$ lac $Z$ cat $) 713$ & Stevens et al. (1992) \\
\hline 731 & $\operatorname{trpC} 2 \Omega($ spoIIIG : :erm C) 731 & Partridge \& Errington (1993) \\
\hline 800 & $\operatorname{met} C 3$ & 806 DNA $\rightarrow$ MB75, Lys ${ }^{+}$selected, screened for $\mathrm{Spo}^{+}$ \\
\hline 801 & $\begin{array}{l}\operatorname{trpC} 2 \text { lac A17 lacR1 spoIIGB55 spoIIIG }{ }^{+}: \text {:pSG139 } \\
(\text { spoIIIG'-'lacZ) }\end{array}$ & Foulger \& Errington (1993) \\
\hline 803 & metC3 cbr: :pPS1395 (gpr'-'lacZ cat) & Foulger \& Errington (1993) \\
\hline 804 & metC3 $\Omega\left(\right.$ spollIG : :ermC) $731 \mathrm{gpr}^{+}:$:pPS1395 (gpr'-'lacZ cat $)$ & Foulger \& Errington (1993) \\
\hline 805 & $\operatorname{metC} 3 \operatorname{ssp} A^{+}::$pPS300 (ssp $A^{\prime}-{ }^{\prime}$ lac $Z$ cat $)$ & Foulger \& Errington (1993) \\
\hline 806 & 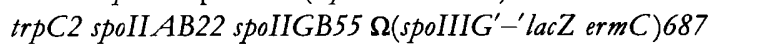 & Foulger \& Errington (1993) \\
\hline 810 & metC3 spoII AB22 gpr $:$ : pPS1395 (gpr'-'lacZ cat) & Foulger \& Errington (1993) \\
\hline 811 & 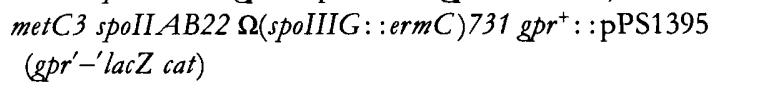 & Foulger \& Errington (1993) \\
\hline 812 & metC3 spoII $A B 22\left(\mathrm{Spo}^{+}\right)$sup-10 $($spoII $A C \mathrm{~K} 247 \mathrm{~T})$ & $\mathrm{Spo}^{+}$revertant of 833 \\
\hline 813 & metC3 spoII $A B 22\left(\mathrm{Spo}^{+}\right)$sup-11 & $\mathrm{Spo}^{+}$revertant of 833 \\
\hline 814 & met $C 3$ spoll $A B 22\left(\mathrm{Spo}^{+}\right)$sup-12 (spoII $\left.A C \mathrm{~S} 222 \mathrm{P}\right)$ & $\mathrm{Spo}^{+}$revertant of 833 \\
\hline 815 & metC3 spoll $A B 22\left(\right.$ Spo $\left.^{+}\right)$sup-13 (spoII $\left.A C \mathrm{~W} 190 \mathrm{G}\right)$ & $\mathrm{Spo}^{+}$revertant of 833 \\
\hline 823 & metC 3 spoII $A B 22 \operatorname{ssp} A^{+}:$:pPS300 $\left(\operatorname{ssp} A^{\prime}-{ }^{\prime}\right.$ lac $Z$ cat $)$ & pPS300 DNA $\rightarrow 800, \mathrm{Cm}^{\mathrm{R}}$ selected \\
\hline 833 & metC3 spoII AB22 & 806 DNA $\rightarrow$ MB75. Lys ${ }^{+}$selected, screened for $\mathrm{Spo}^{-}$ \\
\hline 838 & $\operatorname{trpC} 2$ spoIIIG $G^{+}:$pSG139 (spoIIIG ${ }^{\prime}$ lacZ cat) & pSG139 DNA $\rightarrow 168, \mathrm{Cm}^{\mathrm{R}}$ selected \\
\hline 839 & $\begin{array}{l}\left.\operatorname{trpC} 2 \text { spoII } A B 22 \text { spoIIIG }{ }^{+}: \text {:pSG139 (spoIIIG } G^{\prime}-^{\prime} \text { lac } Z \text { cat }\right) \\
\text { [spoIIGB55] }(\phi 105 \mathrm{~J} 114) \text { spoIIG } A B^{+}\end{array}$ & 843 infected with $\phi 105 \mathrm{~J} 114$ \\
\hline 840 & metC3 spoII $A B 22 \Omega\left(\right.$ spolV $A^{\prime}-$ lac $Z$ cat $) 713$ & 713 DNA $\rightarrow 833, \mathrm{Cm}^{\mathrm{R}}$ selected \\
\hline 841 & $\operatorname{met} C 3 \Omega\left(\right.$ spoIV $A^{\prime}-$ lac $Z$ cat $) 713$ & 713 DNA $\rightarrow 800, \mathrm{Cm}^{\mathrm{R}}$ selected \\
\hline 843 & $\operatorname{trpC} 2$ spoIIGB55 spoIIIG ${ }^{+}:$:pSG139 (spoIIIG ${ }^{\prime}{ }^{\prime}$ lacZ) & $\begin{array}{l}801 \mathrm{DNA} \rightarrow 55.3, \mathrm{Cm}^{\mathrm{R}} \text { selected, screened for blue colony } \\
\text { on plate containing X-Gal }\end{array}$ \\
\hline MB75 & lys-1 metC3 $\left(\mathrm{Spo}^{+}\right)$ & Laboratory stock \\
\hline
\end{tabular}

* Arrows indicate that the DNA was transformed into the strain with the number following; $\mathrm{Cm}^{\mathrm{R}}$, resistance to chloramphenicol. 
based on the hydrolysis of either 4-methylumbelliferyl- $\beta$-Dgalactosidase (MUG assay), or 0 -nitrophenol- $\beta$-D-galactoside (ONPG assay). The MUG assay was done as described by Errington \& Mandelstam (1986), except that the cells were permeabilized by treatment with lysozyme (Mason et al., 1988). One MUG unit of $\beta$-galactosidase activity is the amount of enzyme that produces $1 \mathrm{nmol} 4$-methylumbelliferone $\min ^{-1}$ at $30^{\circ} \mathrm{C}$. The ONPG assay was done as described by Nicholson \& Setlow (1990). The units were as defined by Miller (1972). For assay of $\beta$-galactosidase in cells grown on agar plates, the cells were harvested as described by Rather et al. (1990) and the enzyme activity was determined from a $0.5 \mathrm{ml}$ sample of cell suspension. Alkaline phosphatase (APase) activity was assayed as described by Errington \& Mandelstam (1983). One unit of APase activity is the amount of enzyme that hydrolyses $1 \mathrm{nmol}$ $p$-nitrophenyl phosphate in $1 \mathrm{~min}$ at $30^{\circ} \mathrm{C}$.

Cloning spollAC mutations suppressing the effects of spollAB22. Four $\mathrm{Spo}^{+}$revertants of a spoII AB22 mutant were isolated (strains 812, 813, 814 and 815). Each of the revertants was transformed with an integration plasmid, pSG279, containing a $5^{\prime}$-deleted copy of the spoII $A C$ gene (see earlier). A $\mathrm{Spo}^{-}$colony was isolated from each transformation, on the assumption that the suppressor mutation would be present in the non-functional copy of spoII $A C$ generated during plasmid integration. Chromosomal DNA from each isolate was digested with Pst $\mathrm{I}$. The digests were diluted, religated, and transformed into $E$. coli $\mathrm{DH} 5 \alpha$ with selection for ampicillin resistance. The plasmids recovered were checked for the expected restriction pattern (indistinguishable from that of pSG279).

DNA sequencing. Double-stranded plasmid DNA was sequenced as described previously (Foulger \& Errington, 1993), with a Sequenase kit (USB) and synthetic oligonucleotide primers complementary to the spoII $A$ sequence (ChallonerCourtney \& Yudkin, 1993).

\section{RESULTS}

\section{Effects of the spollAB22 mutation on spore formation}

Some of the effects of the spoIIAB22 mutation on expression of $\sigma^{\mathrm{F}}$ - and $\sigma^{\mathrm{G}}$-dependent genes have been described previously (Foulger \& Errington, 1993). In the course of characterizing the phenotype of the mutant further, we noted that it showed severely impaired spore formation on NA plates. Table 2 shows that the spore frequency on NA plates was less than $1 \%$ of that of the isogenic spoII $A B^{+}$strain, when measured after $26 \mathrm{~h}$.
Although the spore frequencies were somewhat higher in later samples, these estimations are probably less accurate because microscopic examination of the cultures suggested, not surprisingly, that the number of viable cells (but not of spores) fell as the cultures aged. When we tried to quantify the sporulation frequency under the more readily defined conditions of liquid resuspension (Sterlini \& Mandelstam, 1969), we were surprised to find that the sporulation efficiency was near normal (Table 2). It thus seemed that the effect of the spoII AB22 mutation on sporulation was strongly medium-dependent.

\section{Effects of the spollAB22 mutation on gene expression under sporulating and non-sporulating conditions}

We have shown that the activities of both $\sigma^{\mathrm{F}}$ and $\sigma^{\mathrm{G}}$ on $\mathrm{NA}$ are increased in the presence of the spoII $A B 22$ mutation (Foulger \& Errington, 1993). Detailed quantitative analysis of gene expression in plate cultures is problematic because individual cells are exposed to different conditions depending on their location, giving a very heterogeneous population. Rather et al. (1990) reported that the spoII $A B 1$ mutation caused an increased level of $\sigma^{\mathrm{G}}$-dependent gene expression in liquid YT medium, even though this medium does not induce a significant degree of sporulation in either wild-type or mutant strains. We therefore tested the effects of spoII $A B 22$ under similar conditions. As shown in Fig. 1(a), like the spoII $A B 1$ mutation, spoII $A B 22$ increased the expression of a $\sigma^{\mathrm{G}}$-dependent reporter $(\operatorname{ssp} A-l a c Z)$ in liquid YT medium, compared with isogenic spoII $A B^{+}$ cells. Unlike spoII $A B 1$, spoII $A B 22$ also showed an increase in $\sigma^{\mathrm{F}}$ activity (as measured by expression of $g p r^{\prime}-{ }^{\prime}$ lac $Z$ in a spoIIIG background; Fig. 1b) under these non-sporulating conditions. Interestingly, little expression of either $\operatorname{lac} Z$ fusion occurred during vegetative growth but strong induction of expression occurred some hours after the end of exponential growth. Thus, although $\sigma^{\mathbf{F}}$ and $\sigma^{\mathrm{G}}$ are unleashed abnormally in the spoII $A B 22$ mutant, their release is still associated with the stationary phase of the growth cycle. The results also showed that the spoII $A B 22$ mutation can cause substantial inappropriate release of both $\sigma^{\mathrm{F}}$ and $\sigma^{\mathrm{G}}$ activities in liquid culture as well as on solid media.

Table 2. Sporulation efficiencies of wild-type and mutant under different conditions

\begin{tabular}{|c|c|c|c|c|c|c|}
\hline \multirow[t]{3}{*}{ Strain } & \multicolumn{6}{|c|}{ Heat resistant c.f.u. (percentage of viable c.f.u.)* } \\
\hline & \multicolumn{3}{|c|}{ Plate culture $\nmid$} & \multicolumn{3}{|c|}{ Resuspension $\ddagger$} \\
\hline & $26 \mathrm{~h}$ & $48 \mathrm{~h}$ & $71 \mathrm{~h}$ & $5 \mathrm{~h}$ & $7 \mathrm{~h}$ & $9 \mathrm{~h}$ \\
\hline $803\left(\right.$ spoII $\left.A B^{+}\right)$ & $30\left(8.6 \times 10^{7}\right)$ & $52\left(6.5 \times 10^{7}\right)$ & $75\left(7 \cdot 1 \times 10^{7}\right)$ & $7 \cdot 7\left(8 \cdot 9 \times 10^{7}\right)$ & $59\left(7 \cdot 2 \times 10^{7}\right)$ & $55\left(9 \cdot 3 \times 10^{7}\right)$ \\
\hline 810 (spoII AB22) & $0.02\left(1.6 \times 10^{8}\right)$ & $0 \cdot 9\left(5 \cdot 2 \times 10^{7}\right)$ & $6.6\left(4.6 \times 10^{7}\right)$ & $1.8\left(7 \cdot 4 \times 10^{7}\right)$ & $76\left(7 \cdot 5 \times 10^{7}\right)$ & $91\left(7 \cdot 2 \times 10^{7}\right)$ \\
\hline
\end{tabular}

* Viable c.f.u. $\mathrm{ml}^{-1} \mathrm{OD}_{600}{ }^{-1}$ given in parentheses.

$\dagger$ Time after plating on NA.

$\ddagger$ Time after resuspension. 


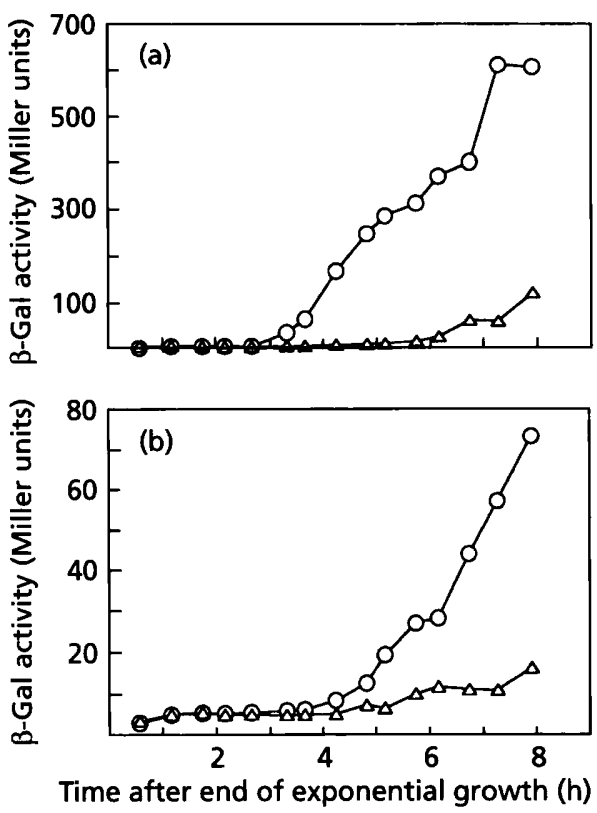

Fig. 1. Effects of the spollaB22 mutation on expression of lacZ fusions to sporulation genes sspA (a) and gpr (b) in liquid YT medium. Each strain was grown overnight in YT medium, then diluted to an $\mathrm{OD}_{600}$ of about $0 \cdot 1$. The growth of the culture was followed and, soon after the end of exponential growth, samples were taken for assay of $\beta$-galactosidase. Each panel shows a comparison of the spollAB22 mutant $(O)$ with an isogenic spoll $A B^{+}$strain $(\triangle)$. The strains in (b) had a mutation in the spolliG gene so that expression due only to the $\sigma^{F}$ form of RNA polymerase was measured. The strains used were 804,805 , 811 and 823.

Table 3. Effect of the spollAB22 mutation on expression of spolvA'-lacZ on NA plates

Mean $\mathrm{OD}_{600}$ values of the cell suspensions are given in parentheses. The times shown indicate hours after plating out on NA.

\begin{tabular}{|c|c|c|c|}
\hline \multirow[t]{2}{*}{ Strain } & \multicolumn{3}{|c|}{$\beta$-Galactosidase activity (Miller units) } \\
\hline & $20 \mathrm{~h}$ & $46 \mathrm{~h}$ & $70 \mathrm{~h}$ \\
\hline 840 (spoII AB22) & $7 \cdot 2(0 \cdot 44)$ & $12(0 \cdot 65)$ & $15(0 \cdot 71)$ \\
\hline $841\left(\right.$ spoII $\left.A B^{+}\right)$ & $16(0 \cdot 62)$ & $36(0 \cdot 89)$ & $35(0 \cdot 63)$ \\
\hline
\end{tabular}

It seemed unlikely that the increased synthesis of $\sigma^{\mathrm{F}}$ - or $\sigma^{\mathrm{G}}$-dependent gene products was entirely responsible for the impairment in sporulation on NA plates. We noted that when a $l a c Z$ fusion to the $\sigma^{\mathrm{E}}$-dependent (mother-cell specific) spoIV $A$ gene was introduced into the spoII $A B$ mutant, the level of $\beta$-galactosidase activity appeared to be reduced compared with spoII $A B^{+}$derivatives, as judged by colony colour on NA plates containing X-Gal. Quantitative measurement of $\beta$-galactosidase in such cultures confirmed that expression of spoIV $A^{\prime}-l a c Z$ was reduced by two- to threefold by the spoII $A B 22$ mutation (Table 3). The reduction in $\sigma^{\mathrm{E}}$ activity may thus contribute to the poor sporulation of this mutant on NA plates.

The greater spore yield following induction of sporulation of the spoII AB22 mutant by the resuspension method suggested that the expression of $\sigma^{\mathrm{F}}$ - and $\sigma^{\mathrm{E}}$-dependent genes would be nearer normal under these conditions than on solid media. Isogenic spoII $A B^{+}$and spoII $A B 22$ strains containing various reporter genes were induced to sporulate by resuspension in SM, and $\beta$-galactosidase activity was measured. In contrast to the results obtained with plate cultures and liquid YT medium, following resuspension strains carrying the spoII $A B 22$ mutation showed, if anything, a reduction in prespore-specific gene expression (Fig. 2a, b). Transcription of both $g p r^{\prime}-{ }^{\prime} l a c Z$ and spoIIIG'-'lacZ increased sharply at about the normal time, but the levels of expression were about twofold less in the spoII $A B 22$ mutants than in the isogenic wild-type strains. Similar results were obtained for $g p r-l a c Z$ when the contribution made by $\sigma^{\mathrm{G}}$ (Sussman \& Setlow, 1991) was eliminated by introducing a spoIIIG mutation, except that the overall levels of expression were reduced about two- to fourfold (Fig. 2a). There was a low but reproducible level of $\beta$-galactosidase activity at the onset of sporulation in the spoII $A B 22$ mutant, when measured either by $g p r^{\prime}-{ }^{\prime}$ lacZ or by spoIII $G^{\prime}-{ }^{\prime}$ lacZ (Fig. 2a, b). This early phase of expression was presumably due mainly to $\sigma^{\mathrm{G}}$ activity because it was abolished by a spoIIIG mutation (Fig. 2a). It was also detected with the ssp $A-l a c Z$ fusion (Fig. 2c), the promoter of which is thought to be recognized specifically by $\sigma^{\mathrm{G}}$ (i.e. not by $\sigma^{\mathrm{F}}$; Sun $e t$ al., 1991). The presence of a low level of $\sigma^{G}$ activity at the time of resuspension in starvation medium probably reflects the fact that the regulation of $\sigma^{\mathbf{G}}$ or, more likely, $\sigma^{\mathbf{F}}$ activity is perturbed in non-sporulating cells carrying the spoII AB22 mutation (see above).

To test the effects of spoII $A B 22$ on $\sigma^{\mathrm{E}}$ activity in cells induced to sporulate by the resuspension procedure, we measured APase. The results of two independent experiments are shown in Fig. 2(d). No consistent differences were observed between the time courses for spoII $A B 22$ and spoII $A B^{+}$strains. Similar results were obtained for a lac $Z$ fusion to the $\sigma^{\mathrm{E}}$-dependent spoIV $A$ gene (data not shown).

In summary, these results confirmed that the phenotypic penetrance of the spoIIAB22 mutation is much less in liquid sporulation medium than in liquid YT medium or on NA plates.

\section{Isolation and characterization of mutations suppressing the effects of the spollAB22 mutation on sporulation on NA}

Plate cultures of spoII $A B$ deletion mutants readily acquire secondary mutations that reduce forespore-specific gene expression (Schmidt et al., 1990; Coppolecchia et al., 1991). These secondary mutations tend to lie in the spoII AC gene (Schmidt et al., 1990; Coppolecchia et al., 1991). Unlike the previously described secondary mutations, some of the ones arising in cultures of the spoII AB22 mutant appeared to restore spore formation. 

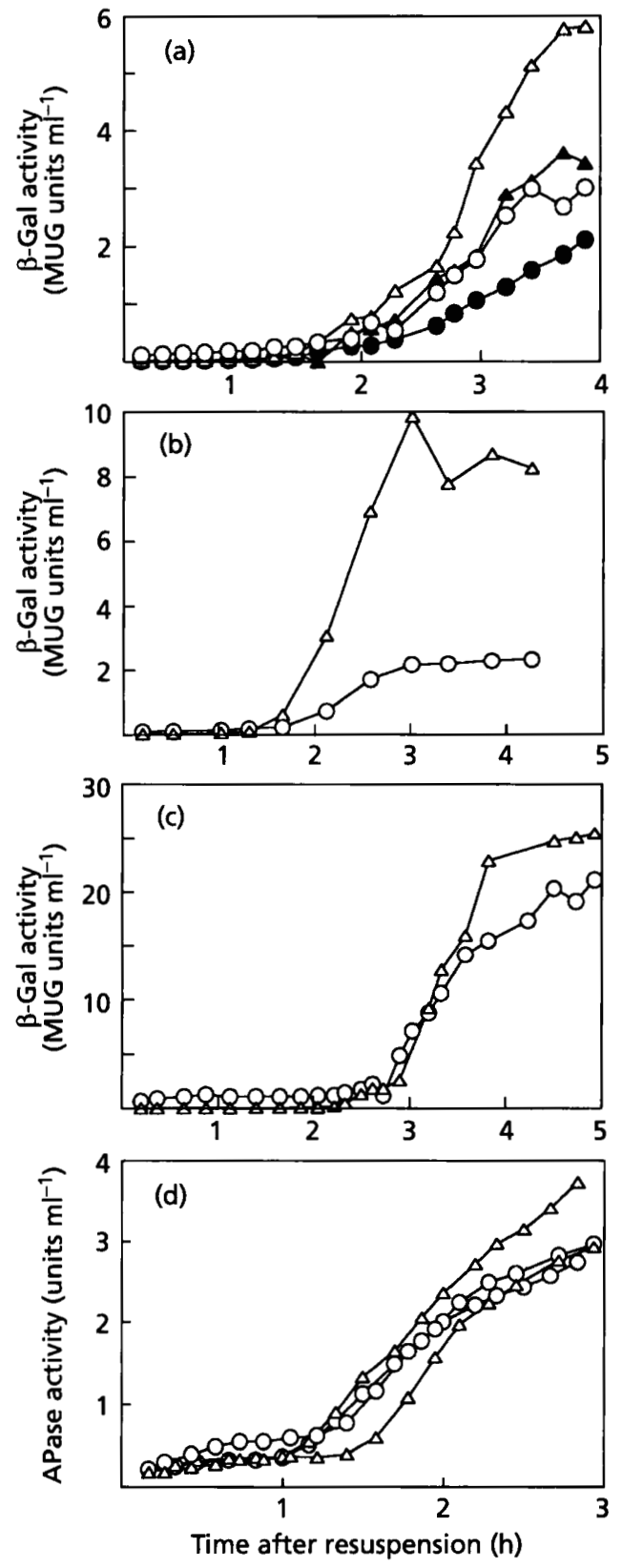

Fig. 2. Effects of the spollAB22 mutation on gene expression during sporulation induced by the resuspension method. In each panel the results obtained with a strain bearing the spollAB22 mutation (triangles) are compared with isogenic spollAB ${ }^{+}$strains (circles). (a) Effects of spollAB22 on expression of gpr-'lacZ, in the presence (open symbols) or absence (filled symbols) of a functional spolliG gene, using strains 803,804 , 810 and 811 ; (b) effects on expression of spollI' ' ' ${ }^{\prime}$ lacZ in strains 838 and 839 ; (c) effects on expression of ssp $A^{\prime}-^{\prime} l a c Z$ in strains 805 and 823; (d) effects on synthesis of APase in strains 803 and 810 - data from two independent experiments are shown.

To determine the nature of these reversion events, four revertants showing increased spore formation were isolated (strains 812, 813, 814 and 815). Each of the revertants was transformed with an integration plasmid, pSG279, containing a deleted copy of spoII $A C$ missing $61 \mathrm{bp}$ from the upstream end. Integration of this plasmid resulted in segregation of $\mathrm{Spo}^{+}$and $\mathrm{Spo}^{-}$colonies, demonstrating that the second mutation was in spoII $A C$, and that the spoII $A B 22$ mutation was still present in the four strains examined. Three of the spoII $A C$ suppressor alleles were recovered by plasmid excision (see Methods). Transformation of the spoII $A B 22$ mutant with each of these plasmids resulted in segregation of $\mathrm{Spo}^{+}$and $\mathrm{Spo}^{-}$ colonies, demonstrating that the plasmids did carry suppressor alleles of spoII $A C$. The inserts in the plasmids were sequenced. All three plasmids contained single base substitutions in the spoII $A C$ gene, which would give rise to single amino acid changes in the $\mathrm{C}$-terminal region of $\sigma^{\mathbf{F}}$ (Fig. 3).

To determine the effects of these suppressor mutations on $\sigma^{\mathbf{F}}$-dependent gene expression in the spoII AB22 mutant, we introduced a spoIIIG - lac $Z$ fusion (which also inactivated the spoIIIG gene) into each of the spoII $A C$ spoII $A B 22$ double mutant strains. In all four cases, the suppressor mutation reduced expression of spoIIIG-lac $Z$ in plate culture to near that of the wild-type (data not shown). The suppressors thus appeared to act by reducing $\sigma^{\mathrm{F}}$-dependent transcription.

\section{DISCUSSION}

Some of the properties of the spoII $A B 22$ mutation are similar to those of the spoII $A B 1$ mutation of Rather $e t$ al. (1990). It exhibited impaired regulation of $\sigma^{\mathrm{G}}$ activity, and the effects were particularly apparent under conditions in which sporulation does not occur (e.g. YT medium; Fig. 1). However, the new mutation differs from spoII $A B 1$ in two important respects. Firstly, it causes a defect not only in the regulation of $\sigma^{\mathrm{G}}$ but also of $\sigma^{\mathrm{F}}$ (Foulger \& Errington, 1993). Secondly, it severely impairs sporulation under certain conditions (Table 2). It is not yet possible to tell whether the increase in $\sigma^{G}$ is the result of an impairment in the interaction between SpoIIAB and $\sigma^{\mathrm{G}}$ or an indirect consequence of the increased $\sigma^{\mathrm{F}}$ activity (see Foulger \& Errington, 1993). However, the fact that the effects on sporulation and gene expression can be bypassed by mutations in the spoII $A C$ gene encoding $\sigma^{\mathrm{F}}$ (Fig. 3) suggests that the regulation of $\sigma^{G}$ activity may be near normal in spoII AB22 mutants (the premature release of a low level of $\sigma^{\mathrm{G}}$ activity in the experiments shown in Fig. 2 could in principle be due to $\sigma^{\mathrm{G}}$ synthesized as a result of a slight release of $\sigma^{F}$ activity). It has not been possible to bypass the effects of either the spoII $A B 28$ missense mutation (Foulger \& Errington, 1993) or spoll $A B$ null mutations by mutating spoII $A C$ in this way (Coppolecchia et al., 1991; D. Foulger and J. Errington, unpublished results). This further indication that the spoII $A B 22$ mutation specifically affects the interaction with $\sigma^{F}$ and not $\sigma^{\mathrm{G}}$ is consistent with our previous suggestion that the $\mathrm{N}$-terminal region of SpoIIAB is involved in sigma-factor recognition (Foulger \& Errington, 1993).

The spoII $A C$ mutations that suppressed the effects of spoII $A B 22$ were scattered throughout the C-terminal coding region of the gene. Their properties gave no specific clues as to the nature of suppression. However, 
1 MDVEVKKNGK NAQLIDHEVK ELIRQSQNGD QQARDLLIEK NMRLVWSVVQ RFLNRGYEPD

Core binding

61 DLFQIGCIGI LKSVDKFDLT YDVRFSTYAV PMIIGEIQRF IRDDGTVKVS RSLKRLGNRI

121 RRAKDEISKT LGRVPTVQBI ADHLEIEAED VVLAQEAVRA PSSIHETVYE NDGDPITLLD

181 OIADNSEEKW FDKIFKKAI SDLEEREKLI VYLRYYKDQT QSEVABRLGI SQVQVSRLEK $\begin{array}{lrrr}\text { G } & \text { P G } & \text { A } \\ 815 & 814 & 224 & 236\end{array}$

$241 \bar{\pi}$ $T$ 812249
Fig. 3. Amino acid sequence of $\sigma^{\mathrm{F}}$ of $B$. subtilis and the substitutions generated by mutations suppressing the effects of the spollAB22 mutation. The amino acids shown in bold face type are those that are conserved among the $B$. subtilis sigma-factor family as shown in the alignment of Stragier et al. (1989). The assignments of the corebinding region and promoter recognition regions are also from Stragier et al. (1989). The substituted amino acid is shown below the residue that it replaces and the allele number of the mutation is given. Alleles 224, 236 and 249 are the suppressors of a spollAB null mutation reported by Coppolecchia et al. (1991). they lie in the same general region of spoII $A C$ as mutations that relieve the toxicity of the increased $\sigma^{\mathrm{F}}$ activity in a spoII $A B$ deletion allele (Coppolecchia et al., 1991). Conceivably, the new suppressor mutations could act simply by reducing the activity of $\sigma^{\mathrm{F}}$. If so, the reduction is probably slight because none of them conferred a $\mathrm{Spo}^{-}$ phenotype in a spoII $A B^{+}$background (D. Foulger and J. Errington, unpublished results).

Why are the effects of the spoII AB22 mutation mediumdependent? One possibility is that the stability of one or more proteins may vary according to environmental conditions. Interestingly, one other class of mutations that can affect the level of $\sigma^{\mathrm{G}}$ activity under various conditions lies in the B. subtilis homologue of the Ion gene of E. coli (Schmidt et al., 1994; D. Foulger and J. Errington, unpublished results). Ion encodes a protease that controls the stability of various proteins, including a number of important regulators (Gottesman, 1987). A second possible explanation for the medium dependence is related to the recent finding that the regulation of $\sigma^{\mathrm{F}}$ activity may be controlled by the ATP/ADP ratio, which is postulated to fall in the prespore (Alper et al., 1994; Diederich et al., 1994). If this model is correct, SpolIAB plays a key role in sensing a threshold level for the ATP/ADP ratio. If the spoII $A B 22$ mutation changed the threshold value, the result would be abnormal release of $\sigma^{\mathrm{F}}$ activity. The likely strong medium-dependence of the ATP/ADP ratio could then explain the effects we have observed.

\section{ACKNOWLEDGEMENTS}

This work was supported by the Science and Engineering Research Council. We thank P. Setlow for plasmids, and R. Schmidt and R. Losick for communicating results ahead of publication.

\section{REFERENCES}

Alper, S., Duncan, L. \& Losick, R. (1994). An adenosine nucleotide switch controlling the activity of a cell type-specific transcription factor in B. subtilis. Cell 77, 195-205.

Anagnostopoulos, C. \& Spizizen, J. (1961). Requirements for transformation in Bacillus subtilis. J Bacteriol 81, 741-746.
Challoner-Courtney, I. J. \& Yudkin, M. D. (1993). Molecular and phenotypic characterization of promoter-proximal mutations in the spoII A locus of Bacillus subtilis. J Bacteriol 175, 5636-5641.

Coppolecchia, R., DeGrazia, H. \& Moran, C. P., Jr (1991). Deletion of spoII $A B$ blocks endospore formation in Bacillus subtilis at an early stage. J Bacteriol 173, 6678-6685.

Diederich, B., Wilkinson, J. F., Magnin, T., Najafi, S. M. A., Errington, J. \& Yudkin, M. D. (1994). Role of interactions between SpoIIAA and SpoIIAB in regulating cell-specific transcription factor $\sigma^{\mathrm{F}}$ of Bacillus subtilis. Genes \& Dev 8, 2653-2663.

Duncan, L. \& Losick, R. (1993). SpoIIAB is an anti- $\sigma$ factor that binds to and inhibits transcription by regulatory protein $\sigma^{\mathbf{F}}$ from Bacillus subtilis. Proc Natl Acad Sci US A 90, 2325-2329.

East, A. K. \& Errington, J. (1989). A new bacteriophage vector for cloning in Bacillus subtilis and the use of $\phi 105$ for protein synthesis in maxicells. Gene 81, 35-43.

Errington, J. (1984). Efficient Bacillus subtilis cloning system using bacteriophage vector $\phi 105 \mathrm{~J} 9$. J Gen Microbiol 130, 2615-2628.

Errington, J. (1993). Bacillus subtilis sporulation: regulation of gene expression and control of morphogenesis. Microbiol Rev 57, 1-33.

Errington, J. \& Mandelstam, J. (1983). Variety of sporulation phenotypes resulting from mutations in a single regulatory locus, spoII A, in Bacillus subtilis. J Gen Microbiol 129, 2091-2101.

Errington, J. \& Mandelstam, J. (1986). Use of a lac $Z$ gene fusion to determine the dependence pattern of sporulation operon spoII $A$ in spo mutants of Bacillus subtilis. J Gen Microbiol 132, 2967-2976.

Errington, J., Fort, P. \& Mandelstam, J. (1985). Duplicated sporulation genes in bacteria: implications for simple developmental systems. FEBS Lett 188, 184-188.

Fort, P. \& Errington, J. (1985). Nucleotide sequence and complementation analysis of a polycistronic sporulation operon, spoV $A$, in Bacillus subtilis. J Gen Microbiol 131, 1091-1105.

Fort, P. \& Piggot, P. J. (1984). Nucleotide sequence of sporulation locus spoII $A$ in Bacillus subtilis. J Gen Microbiol 130, 2147-2153.

Foulger, D. \& Errington, J. (1991). Sequential activation of dual promoters by different sigma factors maintains spoVJ expression during successive developmental stages of Bacillus subtilis. Mol Microbiol 5, 1363-1373.

Foulger, D. \& Errington, J. (1993). Effects of new mutations in the spoII $A B$ gene of Bacillus subtilis on the regulation of $\sigma^{\mathrm{F}}$ and $\sigma^{\mathrm{G}}$ activities. J Gen Microbiol 139, 3197-3203.

Freese, E. \& Heinze, J. (1984). Metabolic and genetic control of bacterial sporulation. In The Bacterial Spore, vol. 2, pp. 101-172. Edited by A. Hurst \& G. W. Gould. London: Academic Press. 
Gottesman, S. (1987). Regulation by proteolysis. In Escherichia coli and Salmonela typhimurium: Cellular and Molecular Biology, pp. 1308-1312. Edited by F. C. Neidhardt, J. L. Ingraham, K. Brooks Low, B. Magasanik, M. Schaechter \& H. E. Umbarger. Washington, DC: American Society for Microbiology.

Jenkinson, H. F. (1983). Altered arrangement of proteins in the spore coat of a germination mutant of Bacillus subtilis. J Gen Microbiol 129, 1945-1958.

Lewis, P. J., Partridge, S.R. \& Errington, J. (1994). $\sigma$ factors, asymmetry, and the determination of cell fate in Bacillus subtilis. Proc Natl Acad Sci US A 91, 3849-3853.

Losick, R. \& Stragier, P. (1992). Crisscross regulation of cell-typespecific gene expression during development in B. subtilis. Nature 355, 601-604.

Margolis, P., Driks, A. \& Losick, R. (1991). Establishment of cell type by compartmentalized activation of a transcription factor. Science 254, 562-565.

Mason, J. M., Hackett, R. H. \& Setlow, P. (1988). Regulation of expression of genes coding for small, acid-soluble proteins of Bacillus subtilis spores: studies using lac $Z$ gene fusions. $J$ Bacteriol 170, 239-244.

Miller, J. H. (1972). Experiments in Molecular Genetics. Cold Spring Harbor, NY: Cold Spring Harbor Laboratory.

Min, K.-T., Hilditch, C. M., Diederich, B., Errington, J. \& Yudkin, M. D. (1993). $\sigma^{\mathrm{F}}$, the first compartment-specific transcription factor of $B$. subtilis is regulated by an anti- $\sigma$ factor that is also a protein kinase. Cell 74, 735-742.

Nicholson, W. L. \& Setlow, P. (1990). Sporulation, germination and outgrowth. In Molecular Biological Methods for Bacillus, pp. 391-450. Edited by C. R. Harwood \& S. M. Cutting. Chichester: Wiley.

Partridge, S.R. \& Errington, J. (1993). The importance of morphological events and intercellular interactions in the regulation of prespore-specific gene expression during sporulation in Bacillus subtilis. Mol Microbiol 8, 945-955.

Partridge, S. R., Foulger, D. \& Errington, J. (1991). The role of $\sigma^{\mathbf{F}}$ in prespore-specific transcription in Bacillus subtilis. Mol Microbiol 5, 757-767.

Piggot, P. J. \& Coote, J. G. (1976). Genetic aspects of bacterial endospore formation. Bacteriol Rev 40, 908-962.
Rather, P. N., Coppolecchia, R., DeGrazia, H. \& Moran, C. P., Jr (1990). Negative regulator of $\sigma^{\mathrm{G}}$-controlled gene expression in stationary-phase Bacillus subtilis. J Bacteriol 172, 709-715.

Sambrook, J., Fritsch, E. F. \& Maniatis, T. (1989). Molecular Cloning: a Laboratory Manual. Cold Spring Harbor, NY: Cold Spring Harbor Laboratory.

Schmidt, R., Margolis, P., Duncan, L., Coppolecchia, R., Moran, C. P., Jr \& Losick, R. (1990). Control of developmental transcription factor $\sigma^{\mathbf{F}}$ by sporulation regulatory proteins SpoIIAA and SpoIIAB in Bacillus subtilis. Proc Natl Acad Sci US A 87, 9221-9225.

Schmidt, R., Decatur, A. L., Rather, P. N., Moran, C. P., Jr \& Losick, R. (1994). Bacillus subtilis Lon protease prevents inappropriate transcription of genes under the control of the sporulation transcription factor $\sigma^{\mathrm{G}}$. J Bacteriol 176, 6528-6537.

Sterlini, J. M. \& Mandelstam, J. (1969). Commitment to sporulation in Bacillus subtilis and its relationship to the development of actinomycin resistance. Biochem $J 113,29-37$.

Stevens, C. M., Daniel, R., Illing, N. \& Errington, J. (1992). Characterization of a sporulation gene, spoIV $A$, involved in spore coat morphogenesis in Bacillus subtilis. J Bacteriol 174, 586-594.

Stragier, P., Kunkel, B., Kroos, L. \& Losick, R. (1989). Chromosomal rearrangement generating a composite gene for a developmental transcription factor. Science 243, 507-512.

Sun, D., Stragier, P. \& Setlow, P. (1989). Identification of a new $\sigma$ factor involved in compartmentalized gene expression during sporulation of Bacillus subtilis. Genes \& Dev 3, 141-149.

Sun, D., Fajardo-Cavazos, P., Sussman, M. D., Tovar-Rojo, F., Cabrera-Martinez, R.-M. \& Setlow, P. (1991). Effect of chromosome location of Bacillus subtilis forespore genes on their spo gene dependence and transcription by $\mathrm{E} \sigma^{\mathrm{F}}$ : identification of features of good $\mathrm{E} \sigma^{\mathrm{F}}$-dependent promoters. $J$ Bacteriol 173, 7867-7874.

Sussman, M. D. \& Setlow, P. (1991). Cloning, nucleotide sequence, and regulation of the Bacillus subtilis gpr gene, which codes for the protease that initiates degradation of small, acid-soluble proteins during spore germination. $J$ Bacteriol 173, 291-300.

Ward, J. B., Jr \& Zahler, S. A. (1973). Genetic studies of leucine biosynthesis in Bacillus subtilis. J Bacteriol 116, 719-726.

Received 5 January 1995; revised 3 March 1995; accepted 20 March 1995. 